\title{
EFFECTS OF AQUEOUS EXTRACT OF VERNONIA KOTSCHYANA SCH. BIP. EX WALP ROOTS ON EXPERIMENTAL GASTRIC ULCER IN MICE
}

\author{
ALEXANDRU VASINCU ${ }^{1}$, DANIELA-CARMEN ABABEI ${ }^{1}$, RĂZVAN-NICOLAE RUSU $^{1}$, \\ GABRIELA DUMITRIȚA STANCIU ${ }^{2}$, SORIN BEŞCHEA CHIRIAC ${ }^{3}$, VERONICA BILD ${ }^{1,2,4}$ \\ I "Grigore T. Popa” University of Medicine and Pharmacy Iasi, Faculty of Pharmacy, Pharmacodynamics and Clinical \\ Pharmacy Department, Iași, Romania \\ 2 "Grigore T. Popa” University of Medicine and Pharmacy, CEMEX Department, Iași, Romania \\ 3 "Ion Ionescu de la Brad” University of Agricultural Sciences and Veterinary Medicine, Faculty of Veterinary Medicine, \\ Iași, Romania \\ ${ }^{4}$ Center of Biomedical Research of the Romanian Academy, Iași, Romania
}

*corresponding author: gdstanciu@yahoo.com

Manuscript received: January 2019

\begin{abstract}
The present study investigated the antiulcer/gastro-protective effects of aqueous extract obtained from Vernonia kotschyana roots on two animal models of gastric ulcer induced by indomethacin and, respectively, absolute ethanol. The extract proved to have weak in vitro antioxidant activity on scavenging free radicals (ABTS radical cation, superoxide and nitric oxide) and weak ability of ferrous ions chelating. FT-IR analysis showed the presence of carbohydrates (polysaccharides) and saponins in the aqueous extract. The results of antiulcer activity study showed that Vernonia aqueous extract is efficient on indomethacin-induced ulcer model $\left(\mathrm{ED}_{50}=557.12 \pm 38.29 \mathrm{mg} / \mathrm{kg}\right.$ b.w. $)$ and has gastro-protective activity on absolute ethanol-induced ulcer model $\left(\mathrm{ED}_{50}=439.85 \pm 5.67 \mathrm{mg} / \mathrm{kg}\right.$ b.w.). Further studies are needed to elucidate other mechanisms through which the aqueous extract exerts antiulcer/gastro-protective effects. Sub-fractionation of the extract may reveal the presence of novel compounds with antiulcer/gastro-protective activity.
\end{abstract}

\section{Rezumat}

Prezentul studiu a investigat efectele antiulceroase/gastro-protectoare ale extractului apos obţinut din rădăcinile speciei Vernonia kotschyana pe două modele animale de ulcer gastric indus de indometacin şi, respectiv, de etanol absolut. Extractul a demonstrat slabe proprietăţi antioxidante in vitro, de scavenger a radicalilor liberi (radicalul cation ABTS, superoxid şi oxid nitric) şi o slabă capacitate de chelatare a ionilor feroşi. În urma analizei FT-IR, în extractul apos au fost identificată prezenţa carbohidraţilor (polizaharide) şi a saponinelor. Rezultatele studiului activităţii antiulceroase au arătat că extractul apos din Vernonia are proprietăţi antiulceroase în cadrul modelului de ulceraţie indusă de indometacin $\left(\mathrm{DE}_{50}=557,12 \pm 38,29 \mathrm{mg} / \mathrm{kg}\right.$ corp) şi proprietăţi gastro-protectoare în cadrul modelului de ulceraţie indusă de etanol $\left(\mathrm{ED}_{50}=439,85 \pm 5,67 \mathrm{mg} / \mathrm{kg} \mathrm{corp}\right)$. Studii ulteriore sunt necesare pentru a elucida alte mecanisme prin care extractul apos exercită acţiune antiulceroasă/gastroprotectoare. Sub-fracţionarea extractului poate dezvălui prezenţa unor noi compuşi cu activitate antiulceroasă/gastroprotectoare.

Keywords: Vernonia kotschyana, antiulcer, gastro-protective effect, indomethacin, absolute ethanol, $\mathrm{ED}_{50}$

\section{Introduction}

Gastric ulcer is one of the most disease affection throughout the world and is considered to be a global health problem [9]. It is estimated that 14.5 million people worldwide are affected by gastric ulcers with a mortality rate of 4.08 million per year [31]. The aetiology of the gastric ulcer disease involves the imbalance between the aggressive and the protective factors of the gastric mucosa [22]. The gastric mucosa is subjected constantly to the aggression of noxious agents, such as gastric acid, pepsin secretion, biliary acids, different ingredients from alimentation, chronic alcohol consumption, infection with Helicobacter pylori, chronic treatment with non-steroidal anti- inflammatory drugs (including aspirin, diclofenac, indomethacin) and reactive oxygen species; these agents stimulate the secretion of acid and pepsin, inhibit the cytoprotective prostaglandins synthesis, decrease the blood flow at gastric level and gastric motility [2, 3]. The protective factors of gastric mucosa are: mucus [19], prostaglandins [39, 48], bicarbonate secretion [21, 44], nitric oxide [20] and growth factors $[10,22]$.

Treatment strategy for gastric ulcer includes available drugs such as antacids, $\mathrm{H}_{2}$ receptor antagonists, proton pump inhibitors, muscarinic $\mathrm{M}_{1}$ and $\mathrm{M}_{3}$ receptor antagonists, antagonists targeting gastrin receptors, somatostatin analogues, drugs that restore and 
regenerate damaged mucosa, antibacterial drugs against Helicobacter pylori. Unfortunately, the therapeutical benefits of these drugs is accompanied by high incidence of side effects and drug interactions [9, 38]. Plants have been used for centuries in traditional medicine by native healers in the prophylaxis and treatment of gastric ulcer. In the last decades, ethnopharmacological studies have been focused on agents in alternative medicine with promising anti-ulcer activity, with decreased relapse and minimal side effects [22, 29]. In order to justify the traditional use, these plants were intensively studied, in order to clarify the mechanism of anti-ulcerous action [38].

Vernonia kotschyana Sch. Bip. ex Walp (Asteraceae family) is an annually tropical African plant [15]. Several ailments such as stomach-ache, tuberculosis, gonorrhoea, gingivitis, arthritis or gastro intestinal disorders are treated in some African countries (Mali, Nigeria, Kenya) by local traditional healers using various parts of the plant [14].

The roots of Vernonia are used in Mali for the treatment of gastritis, stomach ulcers and wounds. Traditional healers recommend the use of dried and powdered roots in gastric dysfunction treatment as a decoction. Starting from these usages, the researchers of the Department of Traditional Medicine in Bamako, Mali obtained and conditioned an Improved Traditional Medicine $\left(\right.$ Gastrosédal $\left.^{\circledR}\right)$ that is on the National List of Essential Drugs [32, 46]. It's efficacy was evaluated in two clinical trials, which confirmed the antiulcerous effect of the preparation [1]. Germano et $a l$. investigated the preventive and/or curative antiulcerous activity of the aqueous extract obtained in maceration of plant roots using different ulcerogenic models [15].

On the basis of the use of this plant in folk medicine of Mali, this study was aimed to evaluate the graded dose-response relationship of an aqueous extract obtained from Vernonia kotschyana in order to establish the median effective dose value $\left(\mathrm{ED}_{50}\right)$ of the antiulcerous and gastroprotective activity.

\section{Materials and Methods}

\section{Plant material and preparation of extract}

The roots of Vernonia kotschyana Sch. Bip ex Walp. were provided by the Department of Traditional Medicine, Bamako, Mali. The identity of the plant material was confirmed by experts from the same department. The vegetal material was dried, pulverized and stored in a cool and dry place, away from light until use. A voucher specimen of the plant product is deposited in the Laboratory of Pharmacognosy, Faculty of Pharmacy, "Grigore T. Popa" U.M.F. Iași, Romania.

The aqueous extract (VA) was obtained following a similar method to the one used in traditional medicine. Thus, the plant material was subjected to infusion, continued by $8 \mathrm{~h}$ of prolonged maceration at room temperature. The obtained extract was filtered, concentrated at reduced pressure, lyophilized and stored at $-20^{\circ} \mathrm{C}$ until use.

Drugs and reagents

Ranitidine, indomethacin, absolute ethanol, sodium carboxymethyl cellulose (CMC) were purchased from Sigma Aldrich (Germany). Physiological saline $(0.9 \%)$ was obtained from B. Braun Melsungen (Germany). Distilled water was obtained from Zentiva (Czech Republic).

Phytochemical study

Quantification of total phenolic content

The total phenolic content was estimated using FolinCiocâlteu reagent following the method of $\mathrm{Li}$ et al. $[24,37]$. The results were expressed as $g$ of gallic acid equivalents per $100 \mathrm{~g}$ of extract. The measurements were performed using an ABLE-JASCO V550 UVVIS spectrophotometer.

Quantification of total saponin content

The total saponin content was estimated using the method described by Li et al., slightly modified [27]. The content of total saponin compounds were expressed as $\mathrm{g}$ of betulinic acid equivalents per $100 \mathrm{~g}$ of extract. The measurements were performed using an ABLE-JASCO V550 UV-VIS spectrophotometer. FT-IR spectroscopic analysis

FT-IR spectrum was recorded on ABB MB3000 FTIR spectrometer from the scan range of $4000-650$ $\mathrm{cm}^{-1}$ with a resolution of $4 \mathrm{~cm}^{-1}$ and with a total accumulation of 16 scans. Spectra processing was carried out using the Horizon MB software [16, 36, 43]. In vitro antioxidant assay

ABTS radical cation scavenging assay. ABTS assay was performed according to the method developed by $\operatorname{Re}$ et al. [7, 33]. Glutathione was the positive control.

Superoxide anion radical scavenging assay. The assay was performed as described by Wang and Luo [45]. Glutathione was used as positive control. Nitric oxide radical scavenging assay. The assay was performed as reported by Tsai et al. with minor changes [40]. L-Ascorbic acid was the positive control.

Ferrous ion chelating ability assay. The assay was done according to Dinis et al. [11]. EDTA was used as positive control.

\section{Experimental animals}

Male Swiss albino mice, weighing 25 - 30 g, provided from "Cantacuzino" Institute, Bucharest, Romania, were used. They were kept in polyethylene cages and maintained under standard housing conditions (temperature of $21.00 \pm 2.00^{\circ} \mathrm{C}$, well-ventilated space, $12 \mathrm{~h}$ light $/ 12 \mathrm{~h}$ dark cycle) in the Laboratory of Experimental Pharmacodynamics, Faculty of Pharmacy, "Grigore T. Popa" U.M.F. Iași, Romania. The animals were allowed for acclimatization two weeks before starting the studies with free access to standard 
FARMACIA, 2019, Vol. 67, 5

commercial food (provided from "Cantacuzino" Institute, Bucharest) and water at libitum. $20 \mathrm{~h}$ prior to each experiment the animals were restricted to food, with free access to water.

The experiments were designed and conducted in accordance with the international bioethical norms of the study on laboratory animals and the specific rules of the Research Ethics Committee of the "Grigore T. Popa" University of Medicine and Pharmacy [12].

\section{Antiulcerous activity study}

Indomethacin-induced gastric ulcer

The experiment was conducted according to the method described by Chattopadhyay et al., with slight modifications [8, 35]. Mice were randomized into 8 groups, each consisting of $8-10$ animals, as follows: negative control group (AUG1), positive control group (AUG3), indomethacin-induced gastric ulcer group (AUG2) and the study groups (AUG4AUG8). The extract/substances were suspended in $0.1 \%$ aqueous $\mathrm{CMC}$ solution immediately before use and administered orally.

The groups received the following substances: AUG1 $0.1 \%$ aqueous $\mathrm{CMC}$ solution (20 mL/kg b.w.), AUG2 indomethacin (18 mg/kg b.w.), AUG3 - indomethacin (18 mg/kg b.w.) + ranitidine (100 mg/kg b.w.), AUG4 - indomethacin (18 mg/kg b.w.) + VA (200 $\mathrm{mg} / \mathrm{kg}$ b.w.), AUG5 - indomethacin (18 mg/kg b.w.) + VA (300 mg/kg b.w.), AUG6 - indomethacin (18 mg/ kg b.w.) + VA (400 mg/kg b.w.), AUG7 - indomethacin (18 mg/kg b.w.) + VA (500 mg/kg b.w.), AUG8 indometacin (18 mg/kg b.w.) + VA (800 mg/kg b.w.). Indomethacin was administered in single dose 30 minutes after the administration of extract/positive control. Four hours later, the animals were sacrificed and the stomachs were removed, opened along the greater curvature, rinsed with physiological saline and lesions were viewed using a magnifying lens.

The degree of ulceration was graded according to the following scale, based on the severity of hyperaemia and haemorrhagic erosions: $0=$ normal mucosa; $0.5=$ hyperaemia; $1=1$ - 2 lesions; $2=2$ severe lesions; $3=$ very severe lesions; $4=$ mucosa with many lesions [13]. The ulcer inhibition was calculated for each group using the following formula:

$$
\% \text { Inhibition }=100-\frac{T}{M} \times 100,
$$

where: $\mathrm{M}=$ inhibition degree in control group; $\mathrm{T}=$ inhibition degree in treated group [25, 35, 47].

The total number of ulcer spots divided by the number of animals gives the ulcer index for each group [8]. Absolute ethanol-induced gastric ulcer

The experiment was conducted according to the method described by Li et al., with slight modifications [26]. Mice were randomly divided into 6 groups, each consisting of $8-10$ animals, including the following: negative control group (PGG1), positive control group (PGG3), absolute ethanol-induced gastric ulcer group (PGG2) and the study groups (PGG4 PGG6). The extract/ranitidine were suspended in $0.1 \%$ CMC-Na mucilage immediately before use and administered orally. Absolute ethanol was administered orally.

The groups received the following substances: PGG1 $0.1 \%$ aqueous CMC solution (20 mL/kg b.w.), PGG2 absolute ethanol (0.2 mL/animal), PGG3 - absolute ethanol $(0.2 \mathrm{~mL} / \mathrm{animal})+$ ranitidine $(100 \mathrm{mg} / \mathrm{kg}$ b.w. $)$, PGG4 - absolute ethanol (0.2 mL/animal) + VA (300 mg/kg b.w.), PGG5 - absolute ethanol $(0.2 \mathrm{~mL} /$ animal) + VA (400 mg/kg b.w.), PGG6 - absolute ethanol ( $0.2 \mathrm{~mL} / \mathrm{animal})+\mathrm{VA}(500 \mathrm{mg} / \mathrm{kg}$ b.w.). The aqueous extract, the suspending vehicle and gastroprotective agent were administered daily for 4 days. In the fourth day, $0.2 \mathrm{~mL}$ absolute ethanol (ulcerogenic agent) was administered orally to all groups, except for the negative control group. The animals were sacrificed and followed the same steps as described above.

The degree of ulceration was graded according to the scale presented above at indomethacin-induced gastric ulcer model. The ulcer inhibition and the ulcer index were calculated as described above.

Statistical analysis

The regression analysis of dose-effect graded relationship was performed to determine $\mathrm{ED}_{50}$ values. The parametric data were analysed by ANOVA. A p value of $<0.05$ was considered statistically significant difference between compared groups.

\section{Results and Discussion}

Low content of phenolic compounds $(1.18 \% \pm 0.04 \%)$, but high content of total saponins $(40.77 \% \pm 10.16 \%)$ were found in VA extract. FT-IR analysis showed the presence of carbohydrates (polysaccharides) and saponins in VA extract (Figure 1). Thus, the absorption bands that are characteristic for saponins are present at $3282-3274 \mathrm{~cm}^{-1}$ (O-H group), $2929 \mathrm{~cm}^{-1}$ (methyl group $), 1620 \mathrm{~cm}^{-1}(\mathrm{C}=\mathrm{C}$ group $)$ and $1026-985 \mathrm{~cm}^{-1}$ $[49,50]$. Absorption bands at approximatively $1000 \mathrm{~cm}^{-1}$ (1026 and $985 \mathrm{~cm}^{-1}$ ) are characteristic for carbohydrates (polysaccharides). Absorption bands at 1120 $933 \mathrm{~cm}^{-1}$ are assigned to $\mathrm{C}-\mathrm{O}$ and $\mathrm{C}-\mathrm{C}$ groups, while those between $1456-1218 \mathrm{~cm}^{-1}$ are due to $\mathrm{O}-\mathrm{C}-\mathrm{H}$, $\mathrm{C}-\mathrm{C}-\mathrm{H}$ and $\mathrm{C}-\mathrm{O}-\mathrm{H}$ groups of the carbohydrates [23]. Spectral data are consistent with previous studies that reported that the Vernonia kotschyana roots contain stigmastane and androstane-type steroid saponin glycosides (called vernoniosides) and carbohydrates (pectic polysaccharides, inulin-type fructans) [1, 32, 34]. 


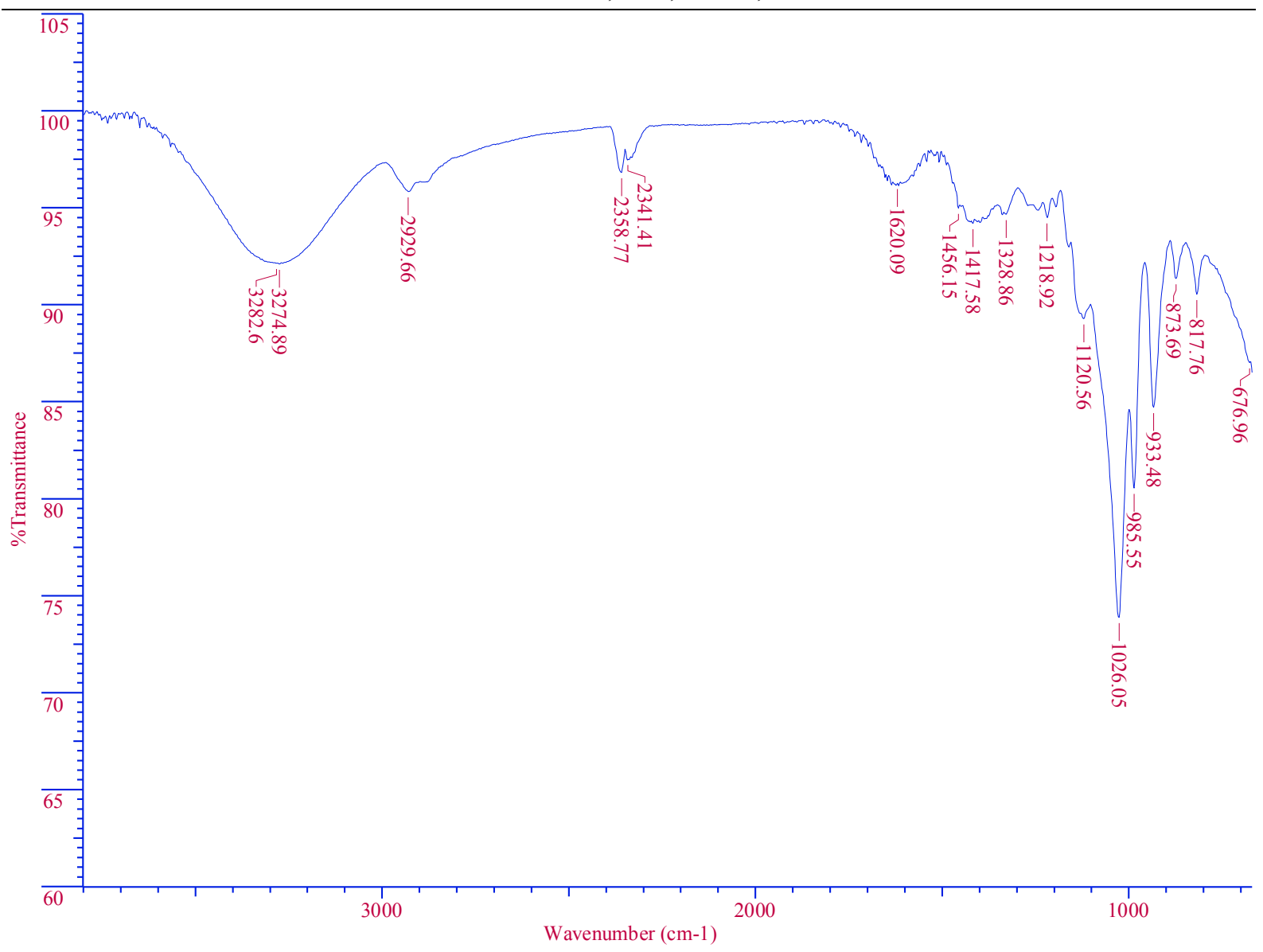

Figure 1.

FT-IR spectra of VA extract

\section{In vitro antioxidant assay}

This study was carried out to determine the in vitro antioxidant activity of Vernonia kotschyana aqueous extract. This aspect is important because it is well known that reactive oxygen species (ROS) and, to a lesser extent, reactive nitrogen species (RNS) are involved in the generation of gastric ulcerations [43]. Antioxidants may help to protect the gastric mucosa against cell damage caused by oxidative stress [5]. The free radical scavenging effects of $V$. kotschyana aqueous extract were initially evaluated against the synthetic nitrogen-cantered 2,2'-azinobis(3-ethylbenzothiazoline-6-sulfonic acid (ABTS) radical cation $[33,43]$. The aqueous extract, tested at a concentration of $40 \mathrm{mg} / \mathrm{mL}$, exhibited a weak scavenging effect after 1, 4 and 6 minutes of reaction: $19.41 \pm 0.58 \%$, $21.43 \pm 0.45 \%$ and, respectively, $22.28 \pm 0.62 \%$.

Further, the scavenging effects against superoxide and nitric oxide radicals [40, 43, 45] and the ferrous ion chelating activity were evaluated $[11,43]$. At the same concentration $(40 \mathrm{mg} / \mathrm{mL})$, the extract showed weak effects of scavenging the superoxide anion and nitric oxide radicals and also weak ability of ferrous ions chelating $(1.35 \pm 0.26 \%, 8.85 \pm 0.47 \%$ and respectively, $13.19 \pm 0.19 \%)$.

\section{Antiulcerous activity study}

The next part of the study was based on a recent research on acute toxicity of some Vernonia kotschyana extracts in mice published by Vasincu et al. It was found that VA extract was not toxic for dose $\leq 3200$ $\mathrm{mg} / \mathrm{kg}$ b.w. [42]. This aspect allowed further investigations concerning the antiulcerous/gastro-protective activity of VA extract.

Indomethacin-induced gastric ulcer

Indomethacin-induced gastric ulcer model was used to test antiulcer activity of VA extract. Indomethacin belongs to the non-selective nonsteroidal antiinflammatory drugs (NSAIDs), which inhibit both COX enzymes and produce damage to the gastric tissue. This effect is related to their ability to suppress cytoprotective prostaglandins synthesis $\left(\mathrm{PGE}_{2}, \mathrm{PGF}_{2}\right.$, $\mathrm{PGI}_{2}$ ) and increase acid secretion. Prostaglandins have an important protective effect on the gastric mucosa. They inhibit gastric acid secretion $\left(\mathrm{PGI}_{2}\right)$, stimulate bicarbonate and mucus secretion $\left(\mathrm{PGE}_{2}\right.$, $\mathrm{PGF}_{2}$ ) and thus maintain an optimal blood flow at gastric mucosal level, regulating mucosal cell turnover and repair [17]. These drugs are widely used in therapy due to their antipyretic, analgesic and antiinflammatory effective properties in a broad spectrum 
FARMACIA, 2019, Vol. 67, 5

of disorders, ranging from common cold to rheumatoid arthritis [28].

The animals of study groups (AUG4 - AUG8) received VA extract using a dose sequence in geometric progression (200 - $800 \mathrm{mg} / \mathrm{kg}$ b.w.). Preliminary data required the use of a dose sequence in arithmetic progression for the studied dose sequence. The obtained data allowed the evaluation of graded dose-effect relationship and led to the determination of $\mathrm{ED}_{50}$ value for antiulcer action. Table I shows the results obtained from macroscopic assessment of indomethacingastric ulcerations.

Table I

The influence of Vernonia kotschyana aqueous extract on indomethacin-induced gastric ulcer

\begin{tabular}{|c|c|c|c|c|}
\hline No & Group & Lesion evaluation & Ulcer index (IU) & \% Inhibition (EMP\%) \\
\hline 1 & AUG1 & 0 & 0 & - \\
\hline 2 & AUG2 & $6.6 \pm 3.1$ & 10 & - \\
\hline 3 & AUG3 & $1.6 \pm 1.2$ & 4 & 75.75 \\
\hline 4 & AUG4 & $7.5 \pm 3.6$ & 8 & pro-ulcerogenic \\
\hline 5 & AUG5 & $5.85 \pm 2.3$ & 7 & 31.09 \\
\hline 6 & AUG6 & $4.2 \pm 1.8$ & 4 & 46.40 \\
\hline 7 & AUG7 & $3.5 \pm 1.5$ & 4 & 64.50 \\
\hline 8 & AUG8 & $2.2 \pm 1.2$ & 3 & Y \\
\hline \multicolumn{5}{|c|}{ Statistical parameters of regression analysis for $50 \%$ activity level } \\
\hline$E_{50}=557.12 \pm 38.29 \mathrm{mg} /$ kg b.w. \\
TCL $(439.52,1096.2)$ \\
Inhibition \% $=39.73$ \\
Total IU $=5$
\end{tabular}

Absolute ethanol-induced gastric ulcer

Absolute ethanol-induced gastric ulcer model was used to test gastro-protective activity of VA extract. The damaging effects of ethanol have been applied to develop the ethanol model of peptic ulcers. The model is independent of gastric acid secretion and resembles acute peptic ulcers in humans [6]. Oral absolute ethanol ingestion in mice model determines acute gastric mucosal lesions through reduction of gastric defensive mechanisms. These are associated with the increased of ROS level [5] and the generation of pro-inflammatory mediators (such as TNF- $\alpha$, IL-6, IL-1 $\beta$ ) that provide an inflammatory circumstance to facilitate the development of acute gastric mucosal lesions [18].
The animals of the study groups (PGG4 - PGG6) received the extract using a dose sequence in arithmetic progression (300 - $500 \mathrm{mg} / \mathrm{kg}$ b.w.). The administration of absolute ethanol caused damage to the gastric mucosa with severe erosions in PGG2 group. Oral administration of VA extract $(300,400$ and $500 \mathrm{mg} / \mathrm{kg}$ b.w.) and ranitidine (100 mg/kg b.w.) significantly inhibited gastric lesions induced by ethanol, compared to the PGG2 group. The obtained data allowed the evaluation of graded dose-effect relationship and led to the determination of $\mathrm{ED}_{50}$ value for gastroprotective action. Table II shows the results obtained from macroscopic assessment of absolute ethanolgastric ulcerations.

Table II

The influence of Vernonia kotschyana aqueous extract on absolute ethanol-induced gastric ulcer

\begin{tabular}{|c|c|c|c|c|}
\hline No & Group & Lesion evaluation & Ulcer index (IU) & \% Inhibition (EMP\%) \\
\hline 1 & PGG1 & 0 & 0 & - \\
\hline 2 & PGG2 & $14.14 \pm 2.29$ & 22 & - \\
\hline 3 & PGG3 & $4.71 \pm 1.17$ & 6 & 67.29 \\
\hline 4 & PGG4 & $10.64 \pm 1.89$ & 11.5 & 26.11 \\
\hline 5 & PGG5 & $7.5 \pm 2.15$ & 9 & 42.95 \\
\hline 6 & PGG6 & $6.16 \pm 3.1$ & 8 & 58.72 \\
\hline \multicolumn{5}{|c|}{ Statistical parameters of regression analysis for $50 \%$ activity level } \\
\hline $\mathrm{ED}_{50}$ & $\begin{array}{l}39.85 \pm \\
\text { L }(367.8 \\
\text { iibition o } \\
\text { Total IU }\end{array}$ & $\begin{array}{l}\mathrm{mg} / \mathrm{kg} \text { b.w. } \\
11.9) \\
2.59 \\
5\end{array}$ & \multicolumn{2}{|c|}{$\begin{array}{c}\mathrm{Y}=-337.02+146.42 * \mathrm{X}, \mathrm{R}=0.994 \\
\left(\mathrm{~F}_{\text {tab }}=161.4 ; \mathrm{F}_{\text {calc }}=343.9\right)\end{array}$} \\
\hline
\end{tabular}

In vitro antioxidant study of VA extract revealed its weak antioxidant properties. It can be noted that the observed gastro-protective effect of VA extract on absolute ethanol-induced gastric ulcer is not probably due to oxidative stress inhibition. The findings of the present antiulcer study and of the in vitro antioxidant study could explain the antiulcer and gastro-protective activity of VA extract. This may be due to the cytoprotective capacity of the aqueous extract of Vernonia kotschyana.

Steroid saponins and polysaccharides were determined in VA extract within the current phytochemical study. 
These constituents play an important role in the antiulcerous activity. Antiulcerous effects for steroid saponins or extracts containing steroid saponins have already been reported in literature. One of the most active steroid saponin is hecogenin that is isolated from Agave sisalana; its gastroprotective effect is due to reduction of lipid peroxidation and NO levels, normalisation of the glutathione level in gastric mucosa, reduction of COX-2 expression and activation of ATP-dependent $\mathrm{K}^{+}$-channels. The latter plays an important role in gastric blood flow regulation, acid secretion and contractility. Saponins activate a number of factors involved in gastric mucosa protection [35]. Polysaccharides, especially peptic ones, provide mechanical protection for the gastric mucosa; in addition, they stimulate mucus production, decrease gastric acidity (hydrochloric acid and pepsinogen) [4], inactivate reactive oxygen species [30] and reduce local production of proinflammatory cytokines (TNF- $\alpha$, IL-6) [41].

\section{Conclusions}

The results of the present study demonstrated that aqueous extract of Vernonia kotschyana roots has antiulcer activity in indomethacin-induced ulcer model $\left(\mathrm{ED}_{50}=557.12 \pm 38.29 \mathrm{mg} / \mathrm{kg}\right.$ b.w. $)$ and gastroprotective activity in absolute ethanol-induced ulcer model $\left(\mathrm{ED}_{50}=439.85 \pm 5.67 \mathrm{mg} / \mathrm{kg}\right.$ b.w. $)$. Because of the weak in vitro antioxidant activity, the observed gastro-protective effect of the extract on absolute ethanol-induced gastric ulcer is not probably due to oxidative stress inhibition.

Further studies, including histological evaluation of the effects of the extract on gastric mucosa, are needed in order to elucidate other mechanisms through which the aqueous extract exerts antiulcerous/gastroprotective effects. Sub-fractionation of the extract may reveal the presence of novel compounds with antiulcerous/gastro-protective activity.

\section{Acknowledgement}

Authors are grateful to Prof. Berit Smestad Paulsen, PhD (University of Oslo, Norway) and Prof. Drissa Diallo, PhD (Department of Traditional Medicine, Bamako, Mali) for providing the plant material. The research was funded by "Grigore T. Popa" University of Medicine and Pharmacy Iași, Romania, based on the contract no 29029/28.12.2016.

\section{References}

1. Austarheim I, Nergard CS, Sanogo R, Diallo D, Inulin-rich fractions from Vernonia kotschyana roots have anti-ulcer activity. $J$ Ethnopharmacol., 2012; 144(1): 82-85.

2. Awan T, Aslam B, Javed I, Khaliq T, Ali A, Sindhu ZUD, Histopathological evaluation of Glycyrrhiza glabra on aspirin induced gastric ulcer in mice. Pak J Agri Sci., 2015; 52(2): 563-568.

3. Boeing T, Da Silva LM, Somensi LB, Cury BJ, Michels Costa AP, Petreanu M, Niero R, De Andrade SF, Antiulcer mechanisms of Vernonia condensata Baker: A medicinal plant used in the treatment of gastritis and gastric ulcer. $J$ Ethnopharmacol., 2016; 184 : 196-207.

4. Borrelli F, Izzo AA, The plant kingdom as a source of anti-ulcer remedies. Phytother Res., 2000; 14 : 581-591.

5. Brito SA, De Almeida CLF, De Santana TI do Nascimento Figueiredo JCB, Souza IT, de Almeida LL, da Silva MV, Borges AS, de Medeiros JW, da Costa Silva Neto J, de Cássia Ribeiro Gonçalves R, Kitagawa RR, Sant'Ana AEG, Rolim LA, de Menezes IRA, da Silva TG, Caldas GFR, Wanderley AG, Antiulcer activity and potential mechanism of action of the leaves of Spondias mombin L. Oxid Med Cell Longev., 2018; 2018: 1-20.

6. Brzozowski T, Konturek P, Konturek S, Kwiecién S, Pajdo R, Brzozowska I, Hahn E, Involvement of endogenous cholecystokinin and somatostatin in gastroprotection induced by intraduodenal fat. J Clin Gastroenterol., 1998; 27(1): S125-S137.

7. Burcu S-U, Sibel D, Turgut T, Mahmoud A, Gul O, Afife M, An evaluation of antioxidant, antimicrobial, antibiofilm and cytotoxic activities of five Verbascum species in Turkey. Farmacia, 2018; 66(6): 1014-1020.

8. Chattopadhyay I, Bandyopadhyay U, Biswas K, Maity $\mathrm{P}$, Banerjee RK, Indomethacin inactivates gastric peroxidase to induce reactive-oxygen-mediated gastric mucosal injury and curcumin protects it by preventing peroxidase inactivation and scavenging reactive oxygen. Free Radic Biol Med., 2006; 40(8): 1397-1408.

9. Choudhary MK, Bodakhe SH, Gupta SK, Assessment of the antiulcer potential of Moringa oleifera rootbark extract in rats. $J$ Acupunct Meridian Stud., 2013; 6(4): 214-220.

10. De Jesus NZT, Falcão HDS, Gomes IF, Leite TJDA, Lima GRDM, Barbosa-Filho JM, Tavares JF, Silva MSD, Athayde-Filho PFD, Batista LM, Tannins, peptic ulcers and related mechanisms. Int J Mol Sci., 2012; 13(3): 3203-3228.

11. Dinis TCP, Madeira VMC, Almeida LM, Action of phenolic derivatives (acetaminophen, saliclyate and 5-aminosalicylate) as inhibitors of membrane lipid peroxidation and peroxyl radical scavengers. Arch Biochem Biophys., 1994; 315: 161-169.

12. Directive 2010/63/UE du Parlement Européen et du Conseil du 22 septembre 2010, relative à la protection des animaux utilisés à des fins scientifiques.

13. Guha P, Dey A, Chatterjee A, Chattopadhyay S, Bandyopadhyay SK, Pro-ulcer effects of resveratrol in mice with indomethacin-induced gastric ulcers are reversed by L-arginine. Br J Pharmacol., 2010; 159(3): 726-734.

14. Ibrahim G, Abdurahman EM, Ibrahim H, Ibrahim NDG, Yaro AH, Studies on acute toxicity and antiinflammatory effects of Vernonia kotschyana Sch. Bip. (Asteraceae) ethanol leaf extract. Nig J Pharm Sci., 2009; 8(2): 8-12. 
15. Ibrahim G, Ogaji YN, Crude flavonoids from Vernonia kotschyana possess antimicrobial activity. Nig J Pharm Sci., 2012; 11(2): 41-49.

16. Imre S, Muntean DL, Principles of drug analysis. Ed. University Press, Târgu-Mureş, 2006; 89-113. (available in Romanian)

17. Joseph JM, Sowndhararajan K, Maniann S, Protective effects of methanolic extract of Hedyotis puberula (G. Don) R. Br. ex Arn. against experimentally induced gastric ulcers in rat. $J$ Ethnopharmacol., 2010; 131: 216-219.

18. Kaur M, Kaur S, Kaur A, Mahajan A, Role of endogenous mediators in peptic ulcer - A review on strategies of pathogenesis and ulcer healing. World J Pharm Pharm Sci., 2014; 3(11): 336-349.

19. Kim H, Hwan Kim K, Role of nitric oxide and mucus in ischemia/reperfusion-induced gastric mucosal injury in rats. Pharmacology, 2001; 62(4): 200-207.

20. Konturek P, Brzozowski T, Walter B, Burnat G, Hess T, Hahn E, Konturek S, Ghrelin-induced gastroprotection against ischemia-reperfusion injury involves an activation of sensory afferent nerves and hyperemia mediated by nitric oxide. Eur J Pharmacol., 2006; 536(1-2): 171-181.

21. Konturek SJ, Konturek PC, Pawlik T, Sliwowski Z, Ochmanski W, Hahn EG, Duodenal mucosal protection by bicarbonate secretion and its mechanisms. $J$ Physiol Pharmacol., 2004; 55(2): 5-17.

22. Kumar K, Mruthunjaya K, Kumar S, Mythreyi R, Anti ulcer activity of ethanol extract of the stem bark of Careya arborea Roxb. Int Curr Pharm J., 2013; 2(3): 78-82.

23. Leopold LF, Leopold N, Diehl HA, Socaciu C, Quantification of carbohydrates in fruit juices using FTIR spectroscopy and multivariate analysis. Spectroscopy, 2011; 26: 93-104.

24. Li H, Cheng K, Wong C, Fan K, Chen F, Jiang Y, Evaluation of antioxidant capacity and total phenolic content of different fractions of selected microalgae. Food Chem., 2007; 102(3): 771-776.

25. Li W, Huang H, Niu X, Fan T, Mu Q, Li H, Protective effect of tetrahydrocoptisine against ethanol-induced gastric ulcer in mice. Toxicol Appl Pharmacol., 2013; 272(1): 21-29.

26. Li W, Yao H, Niu X, Wang Y, Zhang H, Li H, Mu $\mathrm{Q}$, Protective effect of $\delta$-amyrone against ethanolinduced gastric ulcer in mice. Immunobiology, 2015; 220(6): 798-806.

27. Li X, Lin J, Han W, Antioxidant ability and mechanism of rhizoma Atractylodes macrocephala. Molecules, 2012; 17: 13457-13472.

28. Liu YH, Zhang ZB, Zheng YF, Chen HM, Yu XT, Chen XY, Zhang X, Xie JH, Su ZQ, Feng XX, Zeng $\mathrm{HF}$, Su ZR, Gastroprotective effect of andrographolide sodium bisulfite against indomethacin-induced gastric ulceration in rats. Int Immunopharmacol., 2015; 26(2): 384-391.

29. Matran IM, Farcaş A, Bojiţă M, Dumitraşcu DL, Alternative therapies in gastric hypersecretion. Farmacia, 2017; 65(3): 323-328.

30. Matsumoto T, Sun XB, Hanawa T, Kodaira H, Ishii K, Yamada $\mathrm{H}$, Effect of the antiulcer polysaccharide fraction from Bupleurum falcatum L. on the healing of gastric ulcer induced by acetic acid in rats. Phytother Res., 2002; 16(1): 91-93.

31. Mentis A, Lehours P, Mégraud F, Epidemiology and diagnosis of Helicobacter pylori infection. Helicobacter, 2015; 20(1): 1-7.

32. Nergard CS, Diallo D, Michaelsen TE, Malterud KE, Kiyohara H, Matsumoto T, Yamada H, Paulsen BS, Isolation, partial characterisation and immunomodulating activities of polysaccharides from Vernonia kotschyana Sch. Bip. ex Walp. J Ethnopharmacol., 2004; 91(1): 141-152.

33. Re R, Pellegrini N, Proteggente A, Pannala A, Yang $\mathrm{M}$, Rice-Evans $\mathrm{C}$, Antioxidant activity applying an improved ABTS radical cation decolorization assay. Free Radical Biol Med., 1999; 26(9-10): 1231-1237.

34. Sanogo R, Germano MP, Tommasi ND, Pizza C, Aquino R, Vernoniosides and an androstane glycoside from Vernonia kotschyana. Phytochemistry, 1998; 47(1): 73-78.

35. Santos Cerqueira G, Dos Santos E Silva G, Rios Vasconcelos E, Fragoso De Freitas AP, Arcanjo Moura B, Silveira Macedo D, Lopes Souto A, Barbosa Filho JM, De Almeida Leal LK, De Castro Brito GA, Souccar C, De Barros Viana GS, Effects of hecogenin and its possible mechanism of action on experimental models of gastric ulcer in mice. Eur J Pharmacol., 2012; 683(1-3): 260-269.

36. Silverstein RM, Webster FX, Kiemle DJ, Spectrometric identification of organic compounds. $7^{\text {th }}$ edition. John Wiley \& Sons, New York, 2005; 72-126.

37. Singleton VL, Rossi JA, Colorimetry of total phenolics with phosphomolybdic-phosphotungstic acid reagents. Am J Enol Vitic., 1965; 37: 144-158.

38. Steven OO, Uwadiegwu AP, Chinonyelum AN, Chukwu ND, Obianuju OA, Kingsley UI, Chekwube EB, Preliminary studies on the anti-ulcer potentials of Vitex doniana crude extracts on experimental rat model of ethanol induced gastric ulcer. Asian Pac J Trop Dis., 2016; 6(9): 736-740.

39. Takeuchi K, Amagase K, Roles of prostaglandin E and EP receptors in mucosal protection and ulcer healing in the gastrointestinal tract. Arch Dig Disord., 2017; 1(2): 8-16.

40. Tsai PJ, Tsai TH, Yu CH, Ho SC, Evaluation of nosupressing activity of several mediterranean culinary spices. Food Chem Toxicol., 2007; 45: 440-447.

41. Tsuboi M, Takeshita K, Kanamori M, Umemura K, Ogawa K, Akachi N, Yoshida M, Ohno N, Chemical and immunochemical characterization of polysaccharides of Sasa veitchii leaves. Open Pl Sci J., 2013; 7: 1-9.

42. Vasincu A, Ababei DC, Arcan OD, Bulea D, Neamţu M, Chiriac SB, Bild V, Preliminary experimental research on acute toxicity of Vernonia kotschyana extracts in mice. Vet Drug., 2018; 12(1): 57-62.

43. Vasincu A, Paulsen BS, Diallo D, Vasincu I, Aprotosoaie AC, Bild V, Charalambous C, Constantinou AI, Miron A, Gavrilescu CM, Vernonia kotschyana roots: Therapeutic potential via antioxidant activity. Molecules, 2014; 19: 19114-19136.

44. Wallace J, Gastric resistance to acid: Is the "mucusbicarbonate barrier" functionally redundant? Am Physiol Soc., 1989; 256(1 Pt 1): G31-G38.

45. Wang Z, Luo D, Antioxidant activities of different fractions of polysaccharide purified from Gynostemma 
pentaphyllum Makino. Carbohydr Polym., 2007; 68(1): 54-58.

46. Willcox M, Sanogo R, Diakite C, Giani S, Paulsen BS, Diallo D, Improved traditional medicines in Mali. Int J Alt Complement Med., 2012; 18(3): 212-220.

47. Yadav SK, Adhikary B, Chand S, Maity B, Bandyopadhyay SK, Chattopadhyay S, Molecular mechanism of indomethacin-induced gastropathy. Free Radic Biol Med., 2012; 52(7): 1175-1187.
48. Yandrapu H, Sarosiek J, Protective factors of the gastric and duodenal mucosa: An overview. Curr Gastroenterol Rep., 2015; 17(6).

49. Zhou H, Wang CZ, Ye JZ, Chen HX, New triterpene saponins from the seed cake of Camellia oleifera and their cytotoxic activity. Phytochem Lett., 2014; 8: 46-51.

50. Zhou Y, Zeng K, Zhang J, Li N, Chai X, Jiang Y, $\mathrm{Tu} \mathrm{P}$, Triterpene saponins from the roots of Ilex pubescens. Fitoterapia, 2014; 97: 98-104. 